\title{
Vitamin E and reduced glutathione in Prochilodus lineatus (curimba) semen cryopreservation (Characiformes: Prochilodontidae)
}

\author{
Daniella A. J. Paula ${ }^{1}$, Estefânia S. Andrade², Luis D. S. Murgas², Viviane O. Felizardo², \\ Elissandra U. Winkaler ${ }^{3}$, Walmes Zeviani ${ }^{4}$ and Rilke T. F. Freitas ${ }^{1}$
}

This study investigated the addition of antioxidants vitamin $\mathrm{E}$ and reduced glutathione on curimba (Prochilodus lineatus) semen cryopreservation and compared sodium bicarbonate solution and distilled water as activators. The experiment was conducted at the environmental station of CEMIG, in Itutinga-MG, Brazil, between December/2009 and January/2010. Semen samples $(\mathrm{n}=7)$ with semen motility above $80 \%$ were diluted in cryoprotectant solutions composed of $10 \%$ methanol, $15 \%$ lactose and containing different concentrations of antioxidants: 50 (VE50), 100 (VE100) and 250 (VE250) $\mu \mathrm{M}$ of vitamin E, and 0.5 (RG0.5), 1.0 (RG1.0) and 1.5 (RG1.5) mM of reduced glutathione. A solution without antioxidants was used as a control. The semen was diluted at a ratio of 1:4 (100 iL semen: $400 \mu \mathrm{L}$ cryoprotectant solution). The toxicity of the solutions was evaluated by investigating semen motility after $10 \mathrm{~min}$ in the solution. The rest of the diluted semen was placed into $0.5 \mathrm{~mL}$ straws maintained in nitrogen vapour for 24 hours and packed into a nitrogen liquid cylinder for four days. The samples were thawed in a water bath at $60^{\circ} \mathrm{C}$ for $8 \mathrm{~s}$ and the rate $(\%)$ and duration (s) of semen activation with distilled water or sodium bicarbonate was evaluated. In the toxicity test, we found that vitamin $\mathrm{E}$ and reduced glutathione were not toxic to curimba semen at any of the tested concentrations $(\mathrm{P}>0.05)$. The duration of motility was longer $(\mathrm{P}<0.05)$ in semen activated with sodium bicarbonate $1 \%(163 \pm 11 \mathrm{~s})$, which was considered the best activator for semen under these conditions. No significant differences were found between the cryoprotectant solutions used after freezing $(\mathrm{P}>0.05)$. Thus, the antioxidants vitamin $\mathrm{E}$ and reduced glutathione did not improve the quality of cryopreserved curimba semen, but they did not cause toxic effects to the semen in natura and they did not decrease its quality during cryopreservation.

Este estudo avaliou a adição de antioxidantes vitamina E e glutationa reduzida no sêmen criopreservado de curimba (Prochilodus lineatus) e comparou solução de bicarbonato de sódio e água destilada como ativadores. O experimento foi conduzido na estação ambiental da CEMIG, em Itutinga-MG, entre Dezembro/2009 e Janeiro/2010. Sêmen de sete animais, com motilidade espermática acima de $80 \%$, foi diluído em soluções crioprotetoras compostas por metanol $10 \%$ e lactose $15 \%$ em diferentes concentrações de antioxidantes: 50 (VE50), 100 (VE100) e 250 (VE250) $\mu$ M de vitamina E, 0,5 (RG5.5), 1,0 (RG1.0) e 1,5 (RG1.5) $\mathrm{mM}$ glutationa reduzida e uma solução controle sem antioxidante. O sêmen foi diluído na proporção de 1:4 (100 $\mu \mathrm{L}$ de sêmen: $400 \mu \mathrm{L}$ de solução crioprotetora). A toxicidade das soluções foi avaliada pela motilidade espermática após de 10 minutos em solução. O restante do sêmen diluído foi armazenado em palhetas de $0,5 \mathrm{~mL}$ mantidos em vapor de nitrogênio por 24 horas e estocado em cilindro de nitrogênio líquido por quatro dias. As amostras foram descongeladas em banho-maria a $60^{\circ} \mathrm{C}$ por 8 segundos e avaliada a taxa (\%) e duração (s) pela ativação do sêmen com água destilada e bicarbonato de sódio a 1\%. No teste de toxicidade, observamos que os antioxidantes da vitamina $\mathrm{E}$ e glutationa, nas diferentes concentrações, não foram tóxicos para o sêmen do curimba $(\mathrm{P}>0,05)$. A duração da motilidade foi maior $(\mathrm{P}<0,05)$ no sêmen ativado com bicarbonato de sódio, sendo o melhor ativador para o sêmen nestas condições. Não houve diferenças significativas entre as soluções crioprotetoras utilizadas para sêmen antes e após congelamento $(\mathrm{P}>0,05)$. Assim, os antioxidantes vitamina $\mathrm{E}$ e glutationa reduzida não melhoram a qualidade do sêmen criopreservado de curimba, mas não causam efeitos tóxicos para o sêmen in natura e criopreservados por não diminuir sua qualidade durante a criopreservação.

Key words: Antioxidants, Fertilization, Freezing, Reproduction, Sperm motility.

\footnotetext{
${ }^{1}$ Universidade Federal de Lavras, Departamento de Zootecnia, Campus Universitário, 37200-000 Lavras, MG, Brazil. daniufla2002@yahoo.com.br (DAJP), viviofbio@yahoo.com.br(VOF), rilke@dzo.ufla.br (RTFF)

${ }^{2}$ Universidade Federal de Lavras, Departamento de Medicina Veterinária, Campus Universitário, Centro, 37200-000 Lavras, MG, Brazil. esandrade@bol.com.br (ESA)1smurgas@ufla.br (LDSM)

${ }^{3}$ Universidade Federal do Recôncavo da Bahia, Centro de Ciências Agrárias, Ambientais e Biológicas, Centro, 44380-000 Cruz das Almas, BA, Brazil.eliswink@hotmail.com (EUW)

${ }^{4}$ Universidade Federal do Paraná, Departamento de Estatística, Edifício da Administração, $3^{\circ}$ andar,Centro Politécnico, Jardim das Américas, 81.531-990 Curitiba, PR, Brazil. walmes@ufpr.br (WZ)
} 


\section{Introduction}

The curimba (Prochilodus lineatus) is a migratory fish species native to South America (Viveiros et al., 2009). This species has an important role in the ecosystem, as well as in both subsistence and commercial fishing in south-eastern Brazil, with high productivity when maintained in confinement (Maduenho \& Martinez, 2008). As a migratory species, curimba needs to swim upriver to spawn. However, this cycle has been drastically affected by urbanisation, pollution, deforestation, overfishing and the construction of hydroelectric dams and changes in the flow of rivers (Viveiros et al., 2009).

Cryopreservation of fish semen is a method that has been used to promote the preservation of endangered species (Murgas et al., 2007). The cryopreserved semen can be used in captive breeding programmes and for semen banks to ensure genetic diversity and reproductive success (Viveiros et al., 2009). However, cryopreservation can cause changes in spermatozoa protein profiles that may lead to a decreased in semen quality (Li et al., 2010) and affect DNA integrity (Zilli et al., 2003). Furthermore, before the cryopreservation process, it is necessary to dilute the semen in cryoprotective media, and according to Martinez-Páramo et al. (2012), this dilution reduces the seminal plasma constituents, semen becoming more sensitive to oxidative damage.

Fish semen cryopreservation in Brazil has focused on rheophilic species such as the dourado Salminus brasilienses (Carolsfeld et al., 2003), piracanjuba Brycon orbignyanus (Maria et al., 2006), matrinxã Brycon cephalus (Silveira et al., 2006) and curimba $P$. lineatus (Murgas et al., 2007; Felizardo et al., 2010). However, reports of the use of vitamin $\mathrm{E}$ and reduced glutathione associated with cryoprotectant solutions for these species are scarce.

Recent studies in European sea bass (Dicentrarchus labrax) and gilthead sea bream (Sparus aurata) demonstrated no effect on semen motility and viability after cryopreservation, with extenders containing antioxidants such as taurine and hypotaurine ( 1 and $10 \mathrm{mM}$ ), ascorbic acid ( 1 and $10 \mathrm{mM}), \alpha-$ tocopherol $(0.1$ and $0.5 \mathrm{mM})$ or $1 \mathrm{ml} / \mathrm{L}$ of a commercial cell antioxidant supplement (Sigma). However, DNA fragmentation in Dicentrarchus labrax semen was higher in treatments containing vitamins than amino acids or control, and in S. aurata semen the antioxidants taurine and hypotaurine significantly reduced DNA fragmentation parameters, protecting DNA against strand breaks (Cabrita et al., 2011).

The cellular and intracellular membranes are susceptible to attack by free radicals due to the large amount of polyunsaturated fatty acids present in membranes. These lipids make membranes susceptible to lipid peroxidation (LPO) and cause loss of semen function and death (Bilodeau et al., 2002). Reactive oxygen species (ROS) are formed during cryopreservation and the antioxidants can counteract the negative effects of ROS during this process (Thuwanut et al., 2008).

Vitamin E can be used to reduce the damage caused by high concentrations of free radicals, providing protection to the semen DNA and cellular membranes against peroxidation
(Nordberg \& Arner, 2001). Reduced glutathione participates in antioxidant mechanisms, being part of the substrate of the enzyme glutathione peroxidase, which is important during antioxidant processes in cells (Dickinson \& Forman, 2002).

Some previous studies investigated semen cryopreservation using vitamin $\mathrm{E}$ and reduced glutathione in mammals. The authors obtained an increase in the motility of human and dog semen cryopreserved with these antioxidants compared to semen that was cryopreserved without these substances (Askari et al., 1994; Monteiro et al., 2009).

The effects of antioxidants on fish semen are still unclear and the positive effects found in some species may not be true in others. The aims of this study were to determine the effects of vitamin $\mathrm{E}$ and reduced glutathione on the quality of fresh and cryopreserved semen of curimba (P. lineatus) and to determine the efficiency of different semen activators upon the thawing of semen.

\section{Material and Methods}

\section{Animals and semen}

The experiment was conducted between December/2009 and January/2010 at the environmental station of CEMIG, Itutinga, Minas Gerais, Brazil. Seven males weighing an average of $1.66 \pm 0.27 \mathrm{~kg}$, with average semen volume of $6.91 \pm 3.04 \mathrm{~mL}$, motility rate in natura of $99.28 \pm 1.81 \%$ and average semen concentration of $36.4 \pm 2.67 \times 10^{9} \mathrm{semen} / \mathrm{mL}$ were used to perform all the analyses. Their reproductive ability was checked by applying gentle abdominal pressure in order to release semen. The fish were sent to an aquarium where they received intramuscular injections of buserelin acetate $(\mathrm{GnRH}$ analogue gonadotropin-releasing hormone $-0.04 \mathrm{mg} / \mathrm{mL}$ of buserelin acetate -Sincroforte ${ }^{\circledR} /$ Ouro Fino, São Paulo, Brazil) with 0.25 and $0.75 \mathrm{~mL} / \mathrm{kg}$ body weight, respectively, at the base of the dorsal fin with an interval of $12 \mathrm{~h}$ between the two applications.

Twenty-four hours after the initial dose, the urogenital papillae were cleaned and dried with paper towels to prevent contamination and activation of the semen with water, urine or faeces. Then, the coelomic cavity was gently massaged from cranial to caudal direction to promote the release of semen, which was collected in graduated tubes for the determination of semen volume and a macroscopic evaluation of its quality, observable contamination by blood, urine or faeces in semen.

In order to determine the concentration of the semen, 10 $\mu \mathrm{L}$ of semen was diluted (1:1000) in formol citrate and the number of semen cells was estimated using a Neubauer chamber. The number of cells per $\mathrm{mm}^{3}$ was obtained using the formula below. The semen concentration was adjusted to the number of spermatozoa/mL by multiplying the concentration data in $\mathrm{mm}^{3}$ by 1000 .

$\mathrm{SC}=N \times C F$

where:

$S C$ is the semen concentration (semen per $\mathrm{mm}^{3}$ );

$N$ is the number of cells counted in the Neubauer chamber. 
$C F$ is the correction factor, given by:

$C F=(q \times f d) / d$

where:

$q=5$, which is the ratio between the total number of squares of the Neubauer chamber (25) and the number of squares counted (5);

$d f$ is the dilution factor of the semen aliquot $\left(=10^{4}\right)$;

$d$ is the depth between the coverslip and the Neubauer chamber $(=0.1 \mathrm{~mm})$.

\section{Toxicity test}

For the in natura (fresh) motility semen analysis, $10 \mu \mathrm{L}$ of semen diluted in cryoprotectant solutions (10\% methanol, 15 $\%$ lactose and 50 (VE50), 100 (VE100) or 250 (VE250) $\mu \mathrm{M}$ vitamin E, and 0.5 (RG5.5), 1.0 (RG1.0) or 1.5 (RG1.5) mM reduced glutathione, or control solution, from each fish was diluted with $40 \mu \mathrm{L}$ of either distilled water or $1 \%$ sodium bicarbonate (VETEC Química Fina, Rio de Janeiro, RJ, Brazil). These samples were observed using a light microscope (OPTOM TIM-2005-B, JAPAN) with 100x magnification to evaluate semen motility, which was expressed as the mean percentage of mobile semen (0 to 100\%) (Murgas et al., 2007) and semen motility duration (seconds). These observations were made from the time semen was mixed with activator solution until the time when only $\sim 10 \%$ cells were moving.

\section{Cryopreservation}

The semen samples that showed a motility of more than $80 \%$ were diluted in cryoprotectant solutions containing the different antioxidants described above, 10\% methanol and $15 \%$ lactose. The samples were diluted in test-tubes at a ratio of 1:4 (semen:cryoprotectant solution). In order to check the toxicity of the cryoprotectant solution, the rate and duration of semen motility in the diluted semen were analysed according to the methodology used for in natura semen.

The diluted semen in the different solutions was stored in $0.5 \mathrm{~mL}$ straws ( $\mathrm{n}=2$ straws per treatment), which were sealed with sterile surgical clay mass and then cooled under liquid nitrogen vapour (Taylor-Wharton Model CP 300 dry shipper, U.S.A.). The freezing rate was $35.6^{\circ} \mathrm{C} \mathrm{min}{ }^{-1}$ between 21 and $-170^{\circ} \mathrm{C}$. After $24 \mathrm{~h}$, the semen cryopreserved were transferred to the cylinder of liquid nitrogen (MVE Millennium 2000 SC20 CHART, Minnesota, U.S.A.) and stored for 4 days until thawed.

Two straws from each treatment were individually thawed in a water bath at $60^{\circ} \mathrm{C}$ by immersion for $8 \mathrm{~s}$ (Murgas et al., 2007; Felizardo et al., 2010). Then, the straws were dried with paper towels and the ends were cut.

Each $10 \mu \mathrm{L}$ aliquot of semen was deposited on a histological glass slide and motility analysis was performed as described before.

We adopted the experimental design of randomised blocks (DBC), with two replicates in each treatment and seven blocks (fishes). The treatments were arranged in a factorial structure of $2 \times 3 \times 2+1$ (antioxidants, concentrations of antioxidants, activators and control without antioxidants, respectively).
Variables that were not normally distributed were transformed for normalisation and for demonstration then converted again. The results were tested by analysis of variance (ANOVA) using the computer package $\mathrm{R}$ ( $\mathrm{R}$ Development Core Team, 2003).

\section{Results}

\section{Toxicity test}

Semen motility duration and rate ranged from 41 to $632 \mathrm{~s}$ and 70 to $100 \%$, respectively. No significant differences were found in the rate $(\%)$ or duration (s) of semen motility ( $\mathrm{P}>0.05)$ of curimba semen before freezing (toxicity test) with different concentrations of vitamin $\mathrm{E}$ and reduced glutathione (Table 1).

\section{Cryopreservation}

The concentrations of antioxidants used after freezing did not influence $(\mathrm{P}>0.05)$ the rate of semen motility (Table 2$)$. The different antioxidants used did not affect $(\mathrm{P}>0.05)$ the duration of motility (Table 2). Values range from 20 to $95 \%$ for semen motility and from 27 to $408 \mathrm{~s}$ for duration semen.

The activator bicarbonate had a significant positive effect $(\mathrm{P}<0.05)$ on the duration of post-thaw semen motility (Table 2). The duration of semen motility ranged from 192 to $224 \mathrm{~s}$.

\section{Discussion}

\section{Toxicity test}

The toxicity test was conducted to observe if the solutions used to cryopreserve the semen activated or affected the semen quality. It was found that the semen remained immobile for 10 minutes after contact with all solutions tested, confirming that the solutions could be used in cryopreservation studies.

In the toxicity test, we did not find rates lower than $70 \%$ semen motility. Moreover, in comparison to the control treatment, there was no significant difference in motility with

Table 1. Means and standard deviations of the rate (\%) and duration (s) of motility in diluted curimba (P. lineatus) semen before freezing (toxicity test) using different antioxidants and water as activators $(n=7)$. ${ }^{\text {ns }}$ There were no significant difference between treatments ( $\mathrm{P}>0.05)$. VE50: $50 \mu \mathrm{M}$, VE100: $100 \mu \mathrm{M}$ and VE250: $250 \mu \mathrm{M}$ of vitamin E; RG0.5: $0.5 \mathrm{mM}$, RG1.0: $1.0 \mathrm{mM}$ and RG1.5: $1.5 \mathrm{mM}$ of reduced glutathione.

\begin{tabular}{ccc}
\hline Treatments & Rate $(\%)^{\mathrm{ns}}$ & Variables \\
& $94.17 \pm 1.10$ & Duration $(\mathrm{s})^{\mathrm{ns}}$ \\
\hline Control & $90.83 \pm 1.27$ & $218 \pm 6$ \\
VE50 & $93.33 \pm 0.50$ & $85 \pm 4$ \\
VE100 & $96.67 \pm 2.86$ & $88 \pm 22$ \\
VE250 & $94.17 \pm 1.10$ & $95 \pm 17$ \\
RG0.5 & $89.17 \pm 2.44$ & $116 \pm 2$ \\
RG1.0 & $90.00 \pm 1.85$ & $116 \pm 3$ \\
RG1.5 & & \\
\hline
\end{tabular}


Table 2. Means and standard deviations of the rate $(\%)$ of semen motility $(\mathrm{n}=7)$ and duration ( $)$ of curimba (P. lineatus) semen after freeze-thaw (cryopreservation) using different antioxidants $(n=6)$ and using water and bicarbonate as semen activators. ${ }^{n}$ There were no significant differences in the duration of semen motility between treatments $(\mathrm{P}>0.05)$.* There were significant differences between the different activators $(\mathrm{P}<0.05)$. VE50: $50 \mu \mathrm{M}, \mathrm{VE} 100: 100 \mu \mathrm{M}$ and VE250: $250 \mu \mathrm{M}$ of vitamin E; RG0.5: 0.5 mM, RG1.0: $1.0 \mathrm{mM}$ and RG1.5: $1.5 \mathrm{mM}$ of reduced glutathione.

\begin{tabular}{ccccc}
\hline \multirow{2}{*}{ Treatments } & \multicolumn{2}{c}{$\begin{array}{c}\text { Rate of semen motility (\%) } \\
\text { Activators }\end{array}$} & $\begin{array}{c}\text { Duration semen motility (s) } \\
\text { Activators }\end{array}$ \\
\cline { 2 - 5 } & \multicolumn{2}{c}{ Water $^{\mathrm{ns}}$} & Bicarbonate $^{\mathrm{ns}}$ & Water $^{\text {Bicarbonate }}$ \\
\hline Control & $65.71 \pm 2.78$ & $67.86 \pm 2.45$ & $164 \pm 94^{\mathrm{b}}$ & $244 \pm 70^{\mathrm{a}}$ \\
VE50 & $70.00 \pm 5.81$ & $70.71 \pm 4.46$ & $156 \pm 94^{\mathrm{b}}$ & $227 \pm 59^{\mathrm{a}}$ \\
VE100 & $76.86 \pm 4.30$ & $65.00 \pm 0.42$ & $177 \pm 75^{\mathrm{b}}$ & $269 \pm 52^{\mathrm{a}}$ \\
VE250 & $72.14 \pm 7.33$ & $74.29 \pm 6.99$ & $176 \pm 99^{\mathrm{b}}$ & $223 \pm 52^{\mathrm{a}}$ \\
RG0.5 & $67.86 \pm 4.80$ & $76.43 \pm 6.39$ & $147 \pm 86^{\mathrm{b}}$ & $246 \pm 55^{\mathrm{a}}$ \\
RG1.0 & $67.14 \pm 3.70$ & $64.29 \pm 0.08$ & $156 \pm 88^{\mathrm{b}}$ & $235 \pm 64^{\mathrm{a}}$ \\
RG1.5 & $75.71 \pm 9.89$ & $70.00 \pm 3.96$ & $166 \pm 92^{\mathrm{b}}$ & $255 \pm 82^{\mathrm{a}}$ \\
\hline
\end{tabular}

treatments, confirming that the semen used during cryopreservation was viable and not adversely affected by the treatments. Curimba semen with at least $80 \%$ motility is considered a standard of quality for cryopreservation (Viveiros et al., 2009).

The duration of test maintained semen quality, there was semen and cryoprotectant solutions stabilization, considering adequate for freezing of samples and ensure viability. This test, therefore, is an effective method for evaluation of the fish semen before cryopreservation.

\section{Cryopreservation}

Cryopreservation can generate ROS (Watson, 2000) and the use of antioxidants can ameliorate the negative effects produced by ROS (Thuwanut et al., 2008). There are many studies that show the positive effects of antioxidants in semen motility of cryopreserved semen (Askari et al., 1994; Bilodeau et al., 2001; Monteiro et al., 2009). In our study the effect of antioxidant concentration on the rate of semen motility was not significant when compared with the control treatment.

Barros (2007) observed no significant differences in motility and vigour semen (progressive rectilinear movement) in semen from the "gato-do-mato-pequeno" (Leopardus tigrinus), which was cooled at $4^{\circ} \mathrm{C}$ for 24 hours with different concentrations of reduced glutathione $(0,0.5,1.0,1.5 \mathrm{mM})$. However, Askari et al. (1994), who evaluated human semen frozen in liquid nitrogen with $10 \mathrm{mM}$ vitamin $\mathrm{E}$, obtained significant differences $(\mathrm{P}<0.02)$ in the semen motility rate compared to the control group without antioxidant. Monteiro et al. (2009), working with canine semen frozen in liquid nitrogen, obtained high levels of semen motility 90 min post-thaw at a reduced glutathione concentration of 5 $\mathrm{mM}$ compared to $1 \mathrm{mM}$ and to a treatment with no antioxidant. The unexpected results in our study may be explained by the low concentrations of antioxidants used, which may not have been sufficient to obtain significant differences in semen quality.
No significant differences were found in the duration of semen motility with the use of different concentrations of antioxidants; this fact might be due to the short semen handling and manipulation steps reducing ROS action time. Cabrita et al., (2011) working with European sea bass and gilthead sea bream extenders containing several antioxidants suggested a species-specific effect that probably depended on the type of antioxidant added and on its concentration.

Other authors observed in European sea bass a significant improve of total motility $(31.2 \pm 3.0 \%$ and $30.6 \pm 3.9 \%$, respectively) with the addition of $0.1 \mathrm{mM} \alpha$-tocopherol or 1 $\mathrm{mM}$ ascorbic acid to the freezing media a in comparison with the extender control (20.7 $\pm 3.3 \%$ ) (Martinez-Páramo et al., 2012). Our study presents preliminary findings for future studies and reports new data in a freshwater species native fish of Brazil.

The motility semen duration was higher using sodium bicarbonate as the activator in comparison to the use of distilled water. As in most freshwater fish, the duration of semen motility is short due to the inefficiency of mitochondria in supplying the energy demand (Billard, 1992).

When semen motility is activated with $1 \%$ sodium bicarbonate solution, the period of semen motility is increased. This positive effect of bicarbonate as an activator of fish semen has been confirmed by other authors that worked with Brycon orbignyanus and Prochilodus lineatus (Murgas et al., 2001; Murgas et al., 2007). Murgas et al. (2007) found that semen motility lasted 51 to $161 \mathrm{~s}$ and 109 to $184 \mathrm{~s}$ (activated with 60 and $119 \mathrm{mM}$ sodium bicarbonate, respectively) in solutions composed of methanol or dimethyl sulfoxide at concentrations of $10 \%$. The duration of semen motility in fish is short; the longer semen motility with bicarbonate shown in this work is important to increasing the possibility of fertilisation.

In conclusion, the cryoprotectant solution consisting of methanol and lactose together with the antioxidants reduced glutathione and vitamin $\mathrm{E}$ were not toxic to curimba semen ( $P$. lineatus), however it did not exert an effect on the quality of the cryopreserved semen of this species. The best activator for curimba semen after thawing was $1 \%$ sodium bicarbonate.

\section{Acknowledgements}

To the Conselho Nacional de Desenvolvimento Científico e Tecnológico for financial support, to the environmental station of CEMIG of Itutinga (CEMIG-EAI) for their support in this work and the Programa de Pós-Graduação em Zootecnia, Universidade Federal de Lavras.

\section{Literature Cited}

Askari, H. A., J. H. Check, N. Peymer \& A. Bollendorf. 1994. Effect of natural antioxidants tocopherol and ascorbic acids in maintenance of sperm activity during freeze-thaw process. Archives of Andrology, 3: 11-15.

Barros, P. M. H. 2007. Estresse oxidativo e integridade do DNA 
em sêmen resfriado de gato-do-mato-pequeno (Leopardus tigrinus) (SCHREBER, 1775). Unpublished Ph.D. Dissertation, Universidade de São Paulo, São Paulo, 120 p.

Billard, R. 1992. Reproduction in rainbow trout: sex differentiation dynamics of gametogenesis, biology and preservation of gametes. Aquaculture, 100: 263-298.

Bilodeau, J. F., S. Blanchette \& C. Gagnon. 2001. Thiols prevent $\mathrm{H}_{2} \mathrm{O}_{2}$-mediated loss of sperm motility in cryopreserved bull semen. Theriogenology, 56: 275-286.

Bilodeau, J. F., S. Blanchete, N. Cormier \& M. A. Sirad. 2002. Reactive oxygen species-mediated loss of bovine sperm motility in egg yolk Tris extender: protection by pyruvate, metal chelators and bovine liver or oviductal fluid catalase. Theriogenology, 57 : 1105-1122.

Cabrita E., P. Diogo, S. Martínez-Páramo, C. Sarasquete \& M. T. Dinis. 2011. The influence of certain aminoacids and vitamins on post-thaw fish sperm motility, viability and DNA fragmentation. Animal Reproduction Science, 125: 189-195.

Carolsfeld, J., H. P. Godinho, E. Zaniboni Filho \& B. J. Harvey. 2003. Cryopreservation of sperm in Brazilian migratory fish conservation. Journal of Fish Biology, 63: 472-489.

Dickinson, D. A. \& H. J. Forman. 2002. Cellular glutathione and thiols metabolism. Biochemical Pharmacology, 64: 1019-1026.

Felizardo, V. O., R. A. Mello, L. D. S. Murgas, E. S. Andrade, M. M. Drumond \& P. V. Rosa. 2010. Effect of cryopreservant combinations on the motility and morphology of curimba (Prochilodus lineatus) sperm. Animal Reproduction Science, 122: 259-263.

Li, P., M. Hulak, P. Koubek, M. Sulc, B. Dzyuba, S. Boryshpolets, M. Rodina, D. Gela, P. Manaskova-Postlerova, J. Peknicova \& O. Linhart. 2010. Ice-age endurance: the effects of cryopreservation on proteins of sperm of common carp, Cyprinus carpio L. Theriogenology 74: 413-423.

Maduenho, L. P. \& C. B. R. Martinez. 2008. Acute effects of diflubenzuron on the freshwater fish Prochilodus lineatus. Comparative Biochemistry Physiology Part C: Toxicology \& Pharmacology, 148: 265-272.

Maria, N. A., A. T. M. Viveiros, R. T. F. Freitas \& A. V. Oliveira. 2006. Extenders and cryoprotectants for cooling and freezing of piracanjuba (Brycon orbignyanus) semen, an endangered Brazilian teleost fish. Aquaculture, 260: 298-306.

Martínez-Páramo S., P. Diogo, M.T. Dinis, M.P. Herráez, C. Sarasquete \& E. Cabrita. 2012. Incorporation of ascorbic acid and $\alpha$-tocopherol to the extender media to enhance antioxidant system of cryopreserved sea bass sperm. Theriogenology, 77: 1129-1136.

Monteiro, J. C., J. S. A. Gonçalves, J. A. Rodrigues, C. F. Lucio, L. C. G. Silva, M. E. O. A. Assumpção \& C. I. Vannucchi. 2009. Influence of ascorbic acid and glutathione antioxidants on frozenthawed canine semen. Reproduction in Domestic Animals, 44: 359-362.

Murgas, L. D. S., A. Gualhanone, M. O. B. Silva, C. B. Mello, R. T. F. Freitas \& M. G. Zangeronimo. 2001. Calidad seminal del pez piracanjuba (Brycon orbignyanus) post-descongelación. Anales de Veterinária de Murcia, 17: 3-10.

Murgas, L. D. S., A. B. Miliorini, R. T. F. Freitas \& G. J. M. Pereira. 2007. Criopreservação do sêmen de curimba (Prochilodus lineatus) mediante adição de diferentes diluidores, ativadores e crioprotetores. Revista Brasileira de Zootecnia, 36: 526-531.

Nordberg, J. \& E. S. J. Arnér. 2001. Reactive oxygen species, antioxidants and the mammalian thioredoxin system. Free Radical Biology \& Medicine, 31: 1287-1312.
R Development Core Team. R. 2003. A language and environment for statistical computing: version 2.10.1. Viena: Foundation for Statistical Computing. Disponível em: $<$ http://cran. r-project.org/ doc/manuals/ refman.pdf. $>$. Access in: 15 oct. 2009.

Silveira, N. A., F. Foresti, R. V. Silveira \& J. A. Senhorini. 2006. Seminal analysis, cryogenic preservation, and fertility in matrinxã fish, Brycon cephalus (Günther, 1869). Brazilian Archives of Biology and Technology, 49: 651-659.

Thuwanut, P., K. Chatdarong, M. Techakumphu \& E. Axnér. 2008. The effect of antioxidants on motility, viability, acrosome integrity and DNA integrity of frozen-thawed epididymal cat spermatozoa. Theriogenology, 70: 233-240.

Viveiros, A. T., L. H. Orfão, A. N. Maria \& I. B. Allaman. 2009. A simple, inexpensive and successful freezing method for curimba Prochilodus lineatus (Characiformes) semen. Animal Reproduction Science, 112: 293-300.

Watson, P. F. 2000. The causes of reduced fertility of cryopreserved semen. Animal Reproduction Science, 61: 481-492.

Zilli, L., R. Schiavone, V. Zonno, C. Storelli \& S. Vilella. 2003. Evaluation of DNA damage in Dicentrarchus labrax sperm following cryopreservation. Cryobiology, 47: 227-235.

Submitted October 21, 2011

Resubmitted May 8, 2012

Accepted August 8, 2012

Published September 28, 2012 